\title{
Pliegos y normas sobre cemento en España
}

\section{Cement: Administrative tender specifications and standards in Spain}

\author{
FRANCISCO SORIA SANTAMARIA \\ Dr. en Química Industrial \\ ICCET/CSIC \\ ESPANAA
}

Fecha de recepción: 7-IV-91

RESUMEN

Se empieza exponiendo, en orden cronológico, los organismos españoles y documentos elaborados por los mismos relativos a Reglamentos y Normas sobre cementos.

Se justifíca el origen de las primeras reglas para establecer la calidad de los cementos, la aparición de reglamentos por parte de las Administraciones públicas y la elaboración de normas a nivel nacional, en primer término, y los inicios de normas internacionales con motivo del auge de las exportaciones acabada la 2." Guerra Mundial, en segundo lugar.

A continuación se hace un breve resumen de la evolución de los Pliegos de Cemento en España desde 1919 hasta nuestros días, en lo que se refiere a Definiciones, Clasificación, Nomenclatura y Especificaciones.

Finalmente, se incluye en forma tabulada la situación actual de las normas sobre cementos en España.

\section{$S U M M A R Y$}

The paper describes, in chronological order, the different competent Authorities in Spain and the documents issued by them regarding Cement Regulations and Standards.

The origin of the early cement quality Rules is referred to, the issuing of Regulations by the Public Bodies and finally the adoption of National Standards on the one hand, as well as the first initiatives to establish International Standards, especially motivated by the export boom after the Second World War, on the other.

The second part of the paper offers a brief synthesis of the terms and conditions for cement in Administrative Tender Specifications from 1919 to date regarding definitions, classifications and specifications.

Finally the present state of the art is outlined in a series of Tables describing the cement standards in force in Spain.

\section{INTRODUCCION}

A lo largo de este trabajo se manejan dos conceptos: norma y pliego que hay que diferenciar. La Norma es un documento de aceptación voluntaria y el Pliego es un documento de caracter obligatorio, emitido por la Administración.

Históricamente, España se ha regido, en lo que a cementos se refiere, por Órdenes o Decretos Ministeriales, emanados sucesivamente en el tiempo, del Ministerio de Fomento, del Ministerio de Obras Públicas o de la Comisión Permanente Interministerial de Presidencia de Gobierno, de más reciente creación.

\section{INTRODUCTION}

This paper deals with two essential concepts: Standard and Tender Specification. A Standard is a document based on voluntary acceptance, whereas the terms and specifications of a Tender constitute a document of compulsory nature, issued by the Administration.

Historically the Spanish cement sector has been regulated by means of Ministerial Orders and Executive Decrees issued by the competent Department at the time, i.e. by the Ministry of (Industrial) Development, the Ministry of Public Works or the Standing Interministerial Commission attached to the Presidency of the Government, this latter of recent creation. 
En cuanto a normas, en 1949 se crea el instituto Esuañoi òe Normalización baio la denominación ce nstituto de Racionalización del Trabajo (FANOR). En él se crean muy pronto clos Comisiones relacionadas con el cemento: La CT7 "Ensayo de Materiales" y ia $\mathrm{O} ;-41$
As reaards Standards, in 1949 the Spanish Standard's institute was founded, then denomiriated "instituto de Racionalización del Trabajo" (IRANOR). Within this body, iwo committees were set up at a relatively early stage: CT-7 "Material Testing" and CT -41 "Construction",

TAB_L

Regiamentos / normas sobre cementos

\begin{tabular}{|c|c|}
\hline$i 903$ & Pliego de condiciones generales para ei suminisiro de cemenios en cbras públicas \\
\hline 1919 & Fliego general para la recepción de cementos portiand antificiaies en los servicios de obras púbilicas \\
\hline 1930 & Pliego generai de condiciones para la recepción de los aciomerantes hidráulicos en las cbras de carácter cliciai \\
\hline 1946 & $\begin{array}{l}\text { Medificación del pliego general ce conoiciones para la recepción de aglomerantes hiciráulicos en las obras de } \\
\text { carácter oficial }\end{array}$ \\
\hline 1960 & $\begin{array}{l}\text { Pliego generai de condiciones para la recepción de los conglomerantes hidráulicos en ias cbras cie carácter } \\
\text { oficiai ( } \mathrm{PCCH}-61)\end{array}$ \\
\hline 1964 & $\begin{array}{l}\text { Pliego general de condiciones para la recepción de los conglomerantes hidráulicos en las obras de carácter } \\
\text { oticial ( } \mathrm{PCCH}-64)\end{array}$ \\
\hline 1965 & Crden ministerial sobre fomento de la normalización y de la calidad de los congiomerantes hidráulicos \\
\hline $1963-66$ & Normas sobre cemenios basadas en los PCCH-61 y PCCH-64 \\
\hline 1975 & Pliego de prescripciones técnicas generales para la recepción de cementos (RC-75) \\
\hline 1984 & Nuevas normas UNE sobre cementos (basadas en trabajos del CEN y experiencia nacional) \\
\hline 1988 & Pliego de prescripciones técnicas generales para la recepción de cementos (RC-88) \\
\hline
\end{tabular}

TABLE 0

Regulations and standards on cement

\begin{tabular}{|c|c|}
\hline 1903 & Administrative tender specifications for cement suppliers to public works \\
\hline 1919 & General acceptance specifications for artificial portland cements employed in public works \\
\hline 1930 & General acceptance specifications for hydraulic agglomerants used in public works \\
\hline 1946 & Amendments to the general acceptance specifications for hydraulic agglomerants in public works \\
\hline 1960 & General acceptance specifications for hydraulic conglomerants in public works (PCCH-61) \\
\hline 1964 & General acceptance specifications for hydraulic conglomerants in public works (PCCH-64) \\
\hline 1965 & Ministerial order on the promotion of standards and quality of hydraulic conglomerants \\
\hline $1963-66$ & UNE standards for cements, based on $\mathrm{PCCH}-61$ and $\mathrm{PCCH}-64$ \\
\hline 1975 & General Government-issued technical acceptance specifications for cements (RC-75) \\
\hline 1984 & New UNE standards (based on CEN and national experience) \\
\hline 1988 & General government-issued technical acceptance specifications for cements (RC-88) \\
\hline
\end{tabular}


"Construcción"; en la primera se normalizan métodos de ensayo y, en la segunda, especificaciones.

Con anterioridad a 1960 se publicaron tres normas de ensayo, basadas en las normas NELC y en A.S.T.M. (R.I. en puzolánicos, calor de hidratación y superficie específica).

Entre 1963 y 1966 se publicaron siete normas de ensayos y once de nomenclatura y definiciones, basadas on los PCCH-61 y 64.

Desde entonces no se volvieron a publicar más normas UNE.

A principios de 1977 y en el seno de IRANOR, se crea la Comisión CT-80 "Cementos, cales y yesos" con un criterio de representación amplio. Por razones de homogeneidad y funcionalidad, en abril de 1981 se desglosa en dos, a la vez que se equiparan con el esquema de otras Comisiones Internacionales. Así, se mantiene la CT-80 para "Cementos y cales" y se crea la CT-102 para "Yesos y productos del yeso", en consonancia con las correspondientes ISO TC-74 y TC-152.

Con la nueva Comisión CT-80 se pretınndía:

- Revitalizar, potenciar y actualizar la normativa del sector.

- Seguir de cerca las directrices del Comité TC-51 del CEN, con el que se venía colaborando, primero a nivel personal y más tarde a nivel de Comisión, desde su creacción en 1973.

- Recoger el impacto creado por el tema del ahorro enérgético y sus consecuencias en la tipología de los cementos.

- Y, finalmente, canalizar, coordinar y contemplar cuantas sugerencias sirvan para aclarar ideas en el triángulo fabricanteconsumidor-administración.

Por la misma época (Octubre de 1980) y para obviar los múltiples inconvenientes que supone el que varias Instituciones tengan capacidad para dictar Normas o Reglamentos Técnicos, se crea la Comisión Interministerial de Normalización y homologación, disuelta en 1985 y creando simultaneamente el Consejo Superior de Normalización con las siguientes peculiaridades:

- Integración de la Administración con las distintas instancias sociales y económicas interesadas. the former dealing with the standardization of test methods and the latter with specifications.

Until 1960 three test standards had been published based on NELC and ASTM standards (R.I. in pozzolanic cements, hydration heat and specific surface).

Between 1963 and 1966 seven further testing standards were published, as well as eleven nomenclature and definitions standards, based on $\mathrm{PCCH} 61$ and 64.

Since that time no further UNE standards have been issued.

Early in 1977 and within IRANOR, Committee CT80 is created for "cements, lime and gypsum", with ample representation criteria. For reasons of homogeneity and operativeness, in April 1981 this Committee splits into two, thus adapting to the scheme underlying other International Committees. CT-80 is maintained and now competent for "Cements and Limes" whereas the newly set up CT-102 deals with "Gypsum and gypsum products", in conformity with the corresponding ISO bodies, TC-74 and TC-152.

The restructured CT-80 has the following terms of reference:

- Revitalize, potentiate and update the rules and regulations governing the sector.

- First hand information and assessment regarding the guidelines issued by CEN's TC51 with which collabotative activities had been in course, first at a personal, later on at Committee level, ever since its creation in 1973.

- Assess the impact deriving from the general issue of energy savings and its consequences for cement typologies.

- Channel, coordinate and contemplate whatever proposals are put forward to clarify ideas in the triangular interactions between manufacturers, consumers and the Administration.

During the same period (October 1980) and to the purpose of obviating the many inconvenients deriving from the fact that several Institutions enjoyed regulatory powers to issue Standards and Technical Regulations, the Interministerial Standards and Homologation Commission was set up, which upon its dissolution in 1985, was replaced by the High Standardization Council with the following lerms of reference:

- Integrate the respective social and economic partners with the Administration. 
- Asignar al Ministerio de Industria y Energía funciones específicas de Normalización y Certificación. Se crea la Subdirección General de Normalización y Certificación, dependiente de la Dirección General de Innovación Industrial y Tecnología, asumiendo las funciones que venía realizando IRANOR (paso del CSIC al MINER).

- Verter progresivamente al campo de la actividad privada determinados aspectos de la Normalicación y Certificación. Así en 1986 se designa a la Empresa "Asociación Española de Normalización y Certificación" (AENOR) como Entidad reconocida para desarrollar tareas de Normalización y Certificación. En AENOR se funciona con Comités equivalentes a las antiguas Comisiones de IRANOR. Se mantiene la denominación UNE.

\section{NORMAS NACIONALES Y NORMAS INTERNACIONALES}

El cemento ha sido uno de los primeros materiales objeto de normalización y reglamentación.

Lógicamente, esta normativa comenzó a nivel nacional y las primeras reglas para fijar la calidad del producto se editaron hace más de un siglo, a nivel interno de las propias fábricas. Esta iniciativa de las fábricas respondía a la necesidad de crear una imagen de calidad al ser un producto elaborado en plan artesanal por empresas casi de ámbito familiar y un producto nacido del tratamiento, más o menos empírico, de rocas y tierras en estado natural primero (cementos naturales), o por mezclas convenientemente dosificadas después (cementos artificiales).

Más tarde, estos documentos industriales fueron los que manejaron las Administraciones Públicas para hacer sus Reglamentos y Pliegos de Condiciones en Obras Oficiales y, finalmente, por los Organismos Nacionales de Normalización para hacer sus normas. Así surgieron las normas DIN, AFNOR, BS, ASTM, etc.

Hacia los años 20, acabada la Primera Guerra Mundial, llegaron a adquirir importancia las exportaciones de cemento a otros continentes, fenómeno que se acusó fuertemente al acabar la Segunda Guerra Mundial cuando se aumenta bruscamente la producción y sigue en aumento el tonelaje de exportación.

Para facilitar y potenciar estas exportaciones, la industria europea del cemento comenzó a considerar, hacia los años 50 , la necesidad de iniciar trabajos que condujesen a una
- Assign specific Standardization and Certification competences to the Ministry of Industry and Energy. The Subdivision of Standards and Certification is created, which reports to the Division of Industrial Innovation and Technology and assumes the tasks conferred to date upon IRANOR (transfer from CSIC to MINER).

- Gradual transfer to the private sector of certain Standartization and Certification activities. To this purpose the Company "Spanish Association of Standards and Certification" (Asociación Española de Normalización y Certificación - AENOR) was expressly constituted. AENOR operates through Committees with equivalent functions to those of the old IRANOR Committees. The denomination "UNE" for Spanish Standards is maintained.

\section{NATIONAL AND INTERNATIONAL STANDARDS}

Cement has been one of the first materials subjected to standardization and regularization.

The national regulations in this sector are the logical consequence of the first rules issued more than a century ago at a plant-internal level to ensure product quality. This initiative of the cement plants meant a response to the need of creating a quality image, cement then being manufactured on the basis of craftsmanship and familiy tradition in small enterprises. It used to be a product obtained through the more or less empirical treatment of rocks and earths, initially in their natural state (natural cements) and later on the result of conveniently dosed blends (artificial cements).

At a later stage these industrial documents were taken up by the Administration and incorporated into the Regulations and Terms and Specifications of Public tenders for Public Works, ending up with the National Standards Bodies, which built them into their standards. This is how standards, such as DIN, AFNOR, BS, ASTM, etc., came into existence.

Towards the 1920's, right after the First World War, cement exports to other continents were gaining increasing importance, a growing trend which became particularly prominent after the Second World War, when production figures rose sharply and export tonnage growth rates kept increasing.

To the purpose of promoting and potentiating exports, in the early 1950's the European cement industry began to consider the need of initiaiting work which would result in the establishment of 
normalización internacional para unificar, al menos en principio, lo concerniente a los métodos de ensayo.

El cemento es un producto que, rara vez, se emplea sólo y en el que, por lo tanto, no tiene mucho interés la medida directa de sus características esenciales como ocurre, por ejemplo, con el acero.

Por sus peculiaridades de uso, para medir sus cualidades resistentes se establece un mortero convencional en el que es preciso fijar distintas variables:

- Naturaleza y granulometría de la arena.

- Proporción arena-cemento-agua.

- Método de amasado del mortero.

- Método de compactación del mortero.

- Forma y dimensiones de las probetas.

- Condiciones de curado.

- Condiciones de rotura.

Con tantas variables, los posibles valores numéricos de la resistencia, si no se regulan aquéllas, pueden resultar totalmente dispares.

Por lo tanto, era prioritario poner a punto un método internacional para medir la resistencia de los cementos, proceso que fue largo. Se comenzó en el seno de la industria europea (CEMBUREAU); más tarde en colaboración con la RILEM y, finalmente, en el Cometé ISO TC-74, donde acabó siendo una Recomendación a finales de los años 50.

El método fue afortunado. España lo aceptó de inmediato y hoy se aplica prácticamente en toda Europa y algunos países de otros continentes. Algunos (Unión Sovietica, Japón y Brasil) se encuentran en la misma línea, con ligeras divergencias.

En cuanto a normalización internacional debe citarse al CEN (Comité Europeo de Normalización), en cuyo seno existe un Comité, el TC-51, que trata de elaborar unas normas a nivel de la Comunidad Económica Europea, que ya están trascendiendo a nivel de ISO (el Organismo más internacional) y que se espera se proyecten a otras áreas del mundo más alejadas.

\section{EVOLUCIÓN HISTÓRICA DE PLIEGOS Y NORMAS}

Como se dijo en la introducción, España se ha regido, en lo referente a cementos, por Órdenes o Decretos ministeriales. Las normas UNE, editadas por IRANOR, que aparecieron entre 1963 y 1966, international standards to unify, at least in principle, the criteria underlying test methods.

Cement is a product which is only seldom used in isolation. Hence direct measurements of its essential properties, as is of interest with steel, for instance, is practically irrelevant.

In order to measure the different strength properties in cement and considering its peculiar applications, a conventional mortar was established for wich several variables had to be determined:

- The nature and granulometry of sand.

- The sand-cement-water ratio.

- A mortar moulding method.

- A mortar compaction method.

- Specimens shape and dimensions.

- Curing conditions.

- Strength test rupture conditions.

With so many free variables, strength values will result totally arbitrary, unless the former are predetermined.

Therefore, it was a first priority to develop and agree upon an internationally applicable test method for cement strength measurements, which, in fact, proved to be a lengthy process. First steps were taken by the European industry (CEMBUREAU), further action was implemented in cooperation with RILEM and finally the issue was taken up by ISO TC-74, which brought forth a Recomendation in the late 1950's.

The test method proved to be a success. It was inmediatily adopted in Spain, and today it is applied in practically the whole of Europe and some countries in other continents. Others, such as the Soviet Union, Japan and Brazil are moving on similar lines with only slight deviations.

Regarding international standards, the European Standards Committee (CEN) has to be mentioned, whose TC-51 issues draft standards at EEC level, which have proved to expand their sphere of influence beyond the EEC towards ISO (the most internagional organization) and, hopefully, towards other more remote areas.

\section{HISTORICAL EVOLUTION OF TENDER SPECIFICATIONS AND STANDARDS}

As stated in the Introduction, the Spanish cement sector has been regulated by means of Ministerial Orders and Decrees. The UNE standards, issued by IRANOR in 1963 and 1966 were based on the 
se basaban en los pliegos PCCH-61 y PCCH-64, siendo prácticamente una transcripción literal de los mismos.

A partir de 1981, con la creacción de la Comisión CTN-80 "Cementos y Cales" en IRANOR, se comienzan a editar normas UNE, basadas en los documentos que estaba elaborando el Comité TC-51 de CEN que, en principio, no estaban armonizadas con el Pliego entonces vigente (RC75). Esto hizo que la Comisión del Pliego tuviese en cuenta esta circunstancia y se revisara el Pliego RC-75 conduciendo al actual RC-88, en perfecta armonía con las normas UNE publicadas a lo largo de la década de los 80 .

A continuación, se expone de forma abreviada la evolución de los distintos Pliegos en cuatro aspectos:

- Definiciones, clasificación, nomenclatura, designaciones, etc.

- Especificaciones químicas.

- Especificaciones físicas.

- Especificaciones mecánicas.

Definiciones, clasificación, nomenclatura, designaciones, etc.

1919 Un solo tipo de cemento: portland artificial.

1930 Aparece la palabra AGLOMERANTE.

Surgen varios tipos de cemento, sin clases ni categorías.

1946 Aparecen dos clases en los cementos con escoria.

1961 Sustituye la palabra AGLOMERANTE por CONGLOMERANTE.

Aparecen clases y categorías en todos los tipos de cemento $(150,250$ y 350$)$.

Surgen las designaciones: $\mathrm{P}, \mathrm{PS}, \mathrm{PAH}, \mathrm{SC}$, $\mathrm{CA}, \mathrm{NL}$, NR y $\mathrm{CZ}$.

Aparecen el portland resistente a aguas selenitosas (PAS), los blancos y coloreados (PB), los siderúrgicos sobresulfatados (SF) y los naturales (NL y NR).

Surge la denominación de cemento portland comercial.

Aparecen "prescripciones especiales" para todos los cementos:

- cementos de alta estabilidad A.E. terms and specifications of the standard tenders PCCH-61 and PCCH-64, of which they are practically a literary transcription.

As of 1981 and with the nomination of CTN-80 "Cements and Limes" within IRANOR, UNE standards begin to come forth, based on the documents issued by CEN's TC-51 which initially were not harmonized with the standard tender then in force (RC-75). This motivated the Tender Specifications Committee to take this circumstance into account in the revision of $R-75$, which resulted in standard tender specifications $R C-88$ currently in force and in full agreement with the UNE standards published during the 1980's.

In what follows the evolution of the different cement specifications will be briefly described with regard to four aspects:

- Definitions, classification, nomenclature, designations, etc.

- Chemical specifications.

- Physical specifications.

- Mechanical specifications.

Definitions, classification, nomenclature, designations, etc.

1919 One single cement type: Artificial Portland.

1930 The term AGGLOMERANT is acepted.

Several cement types appear, classes and categories still being non-existent.

1946 Two classes are established for slag cement.

1961 The term AGGLOMERANT is replaced by CONGLOMERANT.

Classes and categories are established for all cement types (150, 250 and 350).

The following designations come into use: $P, P S, P A H, S C, C A, N L, N R$ and $C Z$

Sulphatic water resistant Portland (PAS) appears, white and coloured cement (PB), siderurgical and supersulphated cements (SPH) as well as natural varieties (NL and NR).

The denomination "Portland commercial" is introduced.

"Special requirements" come forth for all cement:

- High stability cements: A.E. 
- cementos de bajo calor de h. B.C.

- cementos bajos en álcalis B.A.

1964 Se crean los cementos de adición (incluyendo el SC).

Se desplazan hacia arriba las categorias resistentes (queda 150 sólo para adición y se crea 450 para el $P$.)

Se suprimen los cementos de alta estabilidad.

1975 Cambia el Organismo tutelar (Comisión Interministerial-Presidencia del Gobierno) y el Ámbito (todo tipo de obras).

Se definen componentes (crudos, clínkeres, regulador de fraguado y adiciones - activas $\theta$ inertes-).

Se crean los cementos con adiciones activas (PA) y los cementos compuestos.

Desaparecen el SC y el SF.

Se crean tres niveles de siderúrgicos (S-I, S-II, S-III).

Se crean dos niveles de puzolánicos (PUZ-I y PUZ-II).

Se crean los cementos con propiedades adicionales (sólo portland y compuestos) $A R I, B C, B$ e $Y$

Se suprime la categoría 250 en P y S-I y SII.

Se crea la categoría 550 para P y PA y la 450 para S-I y PUZ-I y PUZ-II.

Se eleva a 200 la categoría de los cementos compuestos (antes de adición).

Se eleva de 450 a 550 la categoría de los aluminosos.

Todo lo anterior supone mejoras o ventajas sobre Pliegos anteriores, pero se incluyen otros criterios poco congruentes:

Se mantienen los cementos naturales.

Se establecen cementos con propiedades adicionales sólo para portland y compuestos, olvidando la resistencia intrínseca al yeso de siderúrgicos y puzolánicos.
- Low heat-of-hydration cements: B.C.

- Low alkali cement: B.A.

1964 Cements with additions are created (including SC).

The strength categories move up the scale (150 remains only for cements with additions and category 450 is developed for $P$ ).

The high stability cements are supress.

1975 The Control Authority changes (Interministerial Commission attached to the Presidency of the Government) as well as the area of competence (for all types of construction works).

Components are defined (raw materials, clinkers, setting regulators and active or inert additions).

Cements with active additions (PA) are developed, as well as composite cements.

SC and SF disappear.

Three levels for siderurgical cement are established (S-I, S-II, S-III).

Two levels for pozzolanic cement are established (PUZ-I and PUZ-II).

Cements with additional and enhanced properties are created (only Portland and composites) ARI, BC, B and $Y$.

Category 250 is eliminated for $P$ and $S-I$ and S-II.

Category 550 is established for $P$ and $P A$, 450 being assigned to S-I, PUZ-I, and PUZII.

The category of composite (previously addition) cements is raised to 200 .

The category of aluminous cement is raised from 450 to 550 .

All these measures mean improvements and benefits as compared to the old tender specifications, but at the same time certain criteria were adopted which seemed to jeopardize the congruency of the above-stated categorization:

Natural cements are maintained.

Enhanced property cements are only defined for Portland and composites, forgetting about intrinsic gypsum strength of siderurgical and pozzolanic cements. 
Se aplica el concepto de ARI a todas las categorías resistentes.

\section{Especificaciones químicas.}

1919 Se habla de módulos: hidráulicos y silícico.

Se limita $\mathrm{MgO}$ (bajo) y $\mathrm{MgO}+\mathrm{SO}_{3}$ (falta desconocimiento sobre mecanismos y sus causas de la expansión).

Se limita $\mathrm{SO}_{3}$ y $\mathrm{S}$ total (hornos verticales, atmósferas reductoras).

1930 Ampliación de límites en portland y supercemento.

Se crea un módulo para cementos de escoria.

Se fija la cal liberada en los cementos puzolánicos.

Se limita $\mathrm{Al}_{2} \mathrm{O}_{3}$ y $\mathrm{Fe}_{2} \mathrm{O}_{3}$ en el cemento aluminoso.

1946 Se fijan algunos límites para los cementos de escoria. (PF., $\mathrm{SO}_{3}, \mathrm{~S}$ total y $\mathrm{CaO}$ ).

1961 Se eleva el RI. y el $\mathrm{SO}_{3}$.

Por primera vez, se establecen límites para la composición potencial (desafortunado $\left.15 \% \rightarrow 18 \% \mathrm{C}_{3} \mathrm{~A}\right)$.

Se establece el índice de puzolanicidad.

1964 Se suprime el límite del $15 \%$ de $C_{3} A$ y se pasa a $18 \%$.

1975 Se eleva el $\mathrm{SO}_{3}$ de 4 a 4,5 para los portland de elevada categoría resistente y siderúrgicos y se reduce a 3,5 para puzolánicos.

Se suprime la limitación del $\mathrm{C}_{3} \mathrm{~A}$ en $18 \%$.

Aparece el gráfico de Fratini para cementos puzolánicos.

Se eleva el $\mathrm{Al}_{2} \mathrm{O}_{3}$ de aluminosos a $36 \%$.

Junto a las mejoras anteriores, se incluye un inconveniente: condicionar el límite del $\mathrm{Rl}$ en los cementos PA con puzolanas, tanto naturales como artificiales.

\section{Especificaciones físicas.}

1919 Se limita la humedad (alta). (Envases de yute, grumos, etc.)
The concept ARI is applied to all strength categories.

Chemical specifications.

1919 The modulus concept is developed: Hydraulic and silicic moduli.

$\mathrm{MgO}$ (low) and $\mathrm{MgO}+\mathrm{SO}_{3}$ are limited (Lack of insight into the mechanisms and causes of expansion).

Total $\mathrm{SO}_{3}$ and $\mathrm{S}$ are limited (vertical furnaces, reducing atmosphere).

1930 Portland and supercement are further limited.

A modulus is established for slag cement.

Lime release in pozzolan cements is established.

Limits for $\mathrm{Al}_{2} \mathrm{O}_{3}$ and $\mathrm{Fe}_{2} \mathrm{O}_{3}$ are established for aluminous cement.

1946 Some limits for slag cement are established (PF, $\mathrm{SO}_{3}$, total $\mathrm{S}, \mathrm{CaO}$ ).

$1961 \mathrm{RI}$ and $\mathrm{SO}_{3}$ limits are raised.

For the first time limits for potencial composition are established (the unfortunate $\left.15 \% \rightarrow 18 \% C_{3} A\right)$.

The pozzolanicity index is introduced.

1964 The $15 \% C_{3} A$ limit is raised to $18 \%$.

$1975 \mathrm{SO}_{3}$ is raised from 4 to 4.5 for high stregth Portland and siderurgical cement and reduced to 3.5 for pozzolanics.

The $18 \% C_{3} A$ limit is withdrawn.

The Fratini curve comes into use for pozzolan cements.

$\mathrm{Al}_{2} \mathrm{O}_{3}$ in aluminous cements is raised to $36 \%$.

Together with these improvements an inconvenient is adopted: The RI limit is conditioned in PA cements with pozzolan, natural as well as artificial types.

Physical specifications.

1919 Humidity limit (high) are introduced (jute containers, clots, etc.). 
Residuos altos en los tamices. (Sistemas de molienda diferentes).

1930 Sigue limitando la humedad.

Residuos más bajos en tamiz y gradual según cemento.

Fraguados normales salvo aluminoso al no estar aclarados los conceptos de fraguado y endurecimiento).

1961 Se suprime el tamiz de 900 mallas $/ \mathrm{cm}^{2}$.

Se crean valores escalonados del peso específico para los cementos siderúrgicos.

1964 Se incluye el ensayo de autoclave para todos los cementos (salvo adición, SF, CA y naturales). ERRORES: exigirlo a los cementos de escoria con más de $5 \% \mathrm{MgO}$ y aplicarlo a cementos puzolánicos.

Establecer, por primera vez, limitación máxima y mínima de superficie específica, manteniendo tamices con residuos altos.

1975 Se suprime la limitación de superficie específica.

Se suprime la limitación en el peso específico.

Se suprime el ensayo de autoclave y se establecen las agujas de Le Chatelier.

Lamentablemente, se mantiene un criterio de finura por tamiz alto e igual para todos los cementos.

\section{Prescripciones mecánicas.}

1919 Resistencias bajas y distintas para todos los tipos.

1930 Dos arenas: dos morteros.

Agua: $1 / 6 \mathrm{P}+38$ (arena de Leucate); $2 / 5 \mathrm{~N}$ + 93 (arena del río Manzanares).

Ensayo en hormigón (supercemento y aluminoso).

Curado a $15-18^{\circ} \mathrm{C}$.

El cemento Zumaya se ensaya en pasta pura.

Ensayo de puzolana con cal.

Resistencias especificadas distintas para todos los tipos de cemento.

1960 Crítica a los valores-límite para edades inferiores a 28 días.
High portion of sieve residues (different grinding systems).

1930 Humidity is further limited.

Sieve residues are reduced, according to cement category.

Normal setting for all the cements except aluminous. (Concepts of setting and hardening non clarified).

1961 The $900 \mathrm{mesh} / \mathrm{cm}^{2}$ sieve is withdrawn.

Graded specific weight values are established for siderurgical cements.

1964 The autoclave assay is included for all cements (except additions, SF, CA and natural cements) ERROR: Apply this requirement to slag cements with over $5 \%$ $\mathrm{MgO}$ as well as to pozzolanic cements.

For the first time maximum and minimum specific surface values are established, maintaining high residue sieves.

1975 The specific surface limits are withdrawn.

Specific weight limits are withdrawn

The autoclave assay is replaced by Chatelier's needles.

Regretfully a high grain size value for sieves is maintained and the same for all cements.

Mechanical requirements.

1919 Low strength values, which are different for each cement type.

1930 Two sand types: Two mortars.

Water: $1 / 6 P+38$ (Leucate sand); $2 / 5 N+$ 93 (sand from the river Manzanares).

Concrete test (supercement and aluminous cement).

Curing and ageing: at $15-18^{\circ} \mathrm{C}$.

Zumaya cement is tested in pure paste.

Lime test for pozzolans.

Different strength values specified for all cement types.

1960 Criticism of limits for ages below 28 days. 
1975 En este Pliego aparecen dos novedades que suponen dos inconvenientes:

- Inclusión como recomendación la resistencia a 3 días en la categoria resistente 350 .

- Creación de un escalón de $100 \mathrm{~kg} / \mathrm{cm}^{2}$ de 7 a 28 d. en compresión y de $10 \mathrm{~kg} / \mathrm{cm}^{2}$ a flexotracción para todos los cementos. Es simplista y perjudica a algunos cementos.

Finalmente, en las tablas $1,2,3,4,5$ y 6 se incluyen los tipos de cemento y las
1975 Two novelties are introduced, which have the effect of an inconvenient:

- In the form of a recomendation: Strength at 3 days for the category 350.

\section{- Establishment of a $100 \mathrm{Kg} / \mathrm{cm}^{2}$} compression stage from 7 to 28 days and $10 \mathrm{Kg} . / \mathrm{cm}^{2}$ in flexotraction for all cements. This is a simplistic criterion and prejudices certain cement types.

In Tables 1 - 6 the cement types and their respective specifications are compiled as they are

TABLA 1

\begin{tabular}{|c|c|c|c|c|c|c|c|}
\hline \multirow{3}{*}{$\begin{array}{c}\text { Tipos de cemento } \\
\text { Denominación }\end{array}$} & \multicolumn{7}{|c|}{ Proporción en masa \% (1) } \\
\hline & \multicolumn{6}{|c|}{ Componentes principales } & \multirow{2}{*}{$\begin{array}{c}\text { Compo- } \\
\text { nentes } \\
\text { adicio- } \\
\text { nales } \\
\text { (2) }\end{array}$} \\
\hline & $\begin{array}{l}\text { Designa- } \\
\text { ción }\end{array}$ & Clínker & $\begin{array}{l}\text { Escoria } \\
\text { Siderur- } \\
\text { gica (S) }\end{array}$ & $\begin{array}{c}\text { Puzolana } \\
\text { Natural } \\
\text { (Z) }\end{array}$ & $\begin{array}{l}\text { Cenizas } \\
\text { Volantes } \\
\text { (C) }\end{array}$ & $\begin{array}{l}\text { Filler } \\
\text { Calizo } \\
\text { (F) }\end{array}$ & \\
\hline \multirow{2}{*}{ Cementos portland } & $1-0$ & 100 & 0 & 0 & 0 & 0 & 0 \\
\hline & 1 & 95 a 99 & - & - & - & - & 1 a 5 \\
\hline $\begin{array}{l}\text { Cemento portland } \\
\text { compuesto }\end{array}$ & II (3) & 65 a 88 & 6 a 27 & \multicolumn{2}{|c|}{6 a 23} & 0 a 5 & - \\
\hline $\begin{array}{l}\text { Cemento portland con } \\
\text { escoria }\end{array}$ & II-S & 65 a 94 & 6 a 35 & - & - & - & 0 a 5 \\
\hline $\begin{array}{l}\text { Cemento portland con } \\
\text { puzolana }\end{array}$ & $11-Z$ & 72 a 94 & - & 6 a 28 & - & - & 0 a 5 \\
\hline $\begin{array}{l}\text { Cemento portland con } \\
\text { ceniza volante }\end{array}$ & $\mathrm{II}-\mathrm{C}$ & 72 a 94 & 一 & - & 6 a 28 & - & 0 a 5 \\
\hline $\begin{array}{l}\text { Cementos portland con } \\
\text { filler calizo }\end{array}$ & $\mathrm{II}-\mathrm{F}$ & 80 a 94 & - & - & - & 6 a 15 & 0 a 5 \\
\hline & III-1 & 40 a 64 & 36 a 60 & - & - & - & 0 a 5 \\
\hline & III-2 & 20 a 39 & 61 a 80 & - & - & - & 0 a 5 \\
\hline Cemento puzolánico & IV & $\geq 60$ & - & \multicolumn{2}{|c|}{$\leq 40$} & - & 0 a 5 \\
\hline Cemento mixto & V & 20 a 64 & \multicolumn{3}{|c|}{36 a $80(4)$} & - & 0 a 5 \\
\hline Cemento aluminoso & $\mathrm{VI}$ & 100 & - & \multicolumn{2}{|c|}{ - } & - & - \\
\hline
\end{tabular}

(1) En estos valores se excluyen: el regulador de fraguado y los aditivos.

(2) Los componentes adicionales pueden ser uno o varios entre escoria siderúrgica, puzolana natural, cenizas volantes o filler calizo, a menos que sean componentes principales del cemento.

(3) Las proporciones de los componentes de los cementos de tipo II deben responder a la fórmula:

$1,0 \mathrm{~S}+1,25 \mathrm{Z}+1,25 \mathrm{C}+1,75 \mathrm{~F} \leq 35$

Cuando la composición de un "cemento portland compuesto" (II) corresponda a la de alguno de los tipos II-S, II-Z, II-C, II-F, será designado concordantemente.

(4) La proporción de puzolana no será superior al $40 \%$. 
especificaciones correspondientes, fijadas hoy día para los cementos, tanto en las normas UNE 80.301-88, como en el vigente Pliego RC-88, el cual se refiere continuamente a aquéllas. Existen, además, especificaciones para los componentes de los cementos (UNE 80.302), para los cementos resistentes a sulfatos y agua de mar (UNE 80.303) y para los cementos blancos (UNE 80.305).

Los cambios más importantes con relación a Pliegos anteriores aluden a las designaciones (números romanos con o sin una letra representativa de la adición) a las categorias resistentes (expresadas en $\mathrm{N} / \mathrm{mm}^{2}$ en vez de en $\mathrm{kg} / \mathrm{cm}^{2}$, con limitaciones superiores e inferiores) y a la mayor profusión de adiciones en tipo y proporciones. in force at present in UNE standards (80.301-88) as well as in the current Tender RC-88 which makes constant reference to UNE standards. In additions, there exist specifications for cement components (UNE 80.302), as well as for sulfate and sea-water resistant cements (UNE 80.303) and white cements (UNE 80.305).

The most important changes vis à vis the now obsolete tenders refer to designations (roman numbers with or without a letter identifying the addition), to the strength categories (expressed in $\mathrm{N} / \mathrm{mm}^{2}$ instead of $\mathrm{Kg} / \mathrm{cm}^{2}$, including upper and lower limits), as well as to the wider range of additives per cement type and the respective ratios.

TABLE 1

\begin{tabular}{|c|c|c|c|c|c|c|c|}
\hline \multirow{3}{*}{$\begin{array}{l}\text { Cement types } \\
\text { Denomination }\end{array}$} & \multicolumn{7}{|c|}{ Mass Ratio \% (1) } \\
\hline & \multicolumn{6}{|c|}{ Principal Components } & \multirow{2}{*}{$\begin{array}{c}\text { Additio- } \\
\text { nal } \\
\text { Compo- } \\
\text { nents } \\
\text { (2) }\end{array}$} \\
\hline & $\begin{array}{l}\text { Desig- } \\
\text { nation }\end{array}$ & Clinker & $\begin{array}{l}\text { Siderur- } \\
\text { gical } \\
\text { Slag (S) }\end{array}$ & $\begin{array}{c}\text { Natural } \\
\text { Pozzolan } \\
\text { (Z) }\end{array}$ & $\begin{array}{l}\text { Flyash } \\
\text { (C) }\end{array}$ & $\begin{array}{l}\text { Lime } \\
\text { Filler } \\
\text { (F) }\end{array}$ & \\
\hline \multirow{2}{*}{ Portland cements } & $1-0$ & 100 & 0 & 0 & 0 & 0 & 0 \\
\hline & 1 & $95-99$ & - & - & - & - & $1-5$ \\
\hline $\begin{array}{l}\text { Portland-composite } \\
\text { cement }\end{array}$ & II (3) & $65-88$ & $6-27$ & \multicolumn{2}{|c|}{$6-23$} & $0-5$ & - \\
\hline Portland-slag cement & II-S & $65-94$ & $6-35$ & - & - & - & $0-5$ \\
\hline $\begin{array}{l}\text { Portland-pozzolana } \\
\text { cement }\end{array}$ & $\| 1-Z$ & $72 \cdot 94$ & - & $6-28$ & - & - & $0-5$ \\
\hline $\begin{array}{l}\text { Portland-fly ash } \\
\text { cement }\end{array}$ & II-C & $72-94$ & - & - & $6-28$ & - & $0-5$ \\
\hline Portland-filler cement & II-F & $80-94$ & - & - & - & $6-15$ & $0-5$ \\
\hline \multirow{2}{*}{ Blastfurnace cement } & III-1 & $40-64$ & $36-60$ & - & - & - & $0-5$ \\
\hline & $\mid I I-2$ & $20-39$ & $61-80$ & - & - & - & $0-5$ \\
\hline Pozzolanic cement & IV & $\geq 60$ & - & \multicolumn{2}{|c|}{$\leq 40$} & - & $0-5$ \\
\hline Mixed cement & V & $20-64$ & \multicolumn{3}{|c|}{$36-80(4)$} & - & 0.5 \\
\hline Aluminous cement & $\mathrm{VI}$ & 100 & - & \multicolumn{2}{|c|}{-} & - & - \\
\hline
\end{tabular}

(1) Excluded from these values: The setting regulator and additives.

(2) The additional components may be one or several for siderurgical slag, natural pozzolan, flyashes or filler, unless they are prencipal cement components.

(3) The cement components (type II) shall comply with the formulas:

$$
1,0 \mathrm{~S}+1,25 \mathrm{Z}+1,25 \mathrm{C}+1,75 \mathrm{~F} \leq 35
$$

In case the composition of "composite Portland cement" (II) corresponds to that of one of the types II-S, II-Z, II-C, II-F, such fact shall be duly indicated.

(4) The natural pozzolan portion shall not surpass $40 \%$. 
TABLA 2

Categorias resistentes y clases de cementos I a IV

\begin{tabular}{|c|c|c|c|c|c|}
\hline \multirow{2}{*}{$\begin{array}{l}\text { Calegorias } \\
\text { Resistentes }\end{array}$} & \multirow{2}{*}{ Clases } & \multicolumn{4}{|c|}{ Resistencias compresión (N/mm²) } \\
\hline & & $\begin{array}{l}\text { Mínimas a } \\
2 \text { días }\end{array}$ & $\begin{array}{c}\text { Mínimas a } \\
7 \text { días }\end{array}$ & $\begin{array}{l}\text { Minimas a } \\
28 \text { dias }\end{array}$ & $\begin{array}{l}\text { Máximas } \\
28 \text { días }\end{array}$ \\
\hline \multirow{2}{*}{ Muy alta } & $55 \mathrm{~A}$ & 30 & - & \multirow{2}{*}{55} & \multirow{2}{*}{ - } \\
\hline & 55 & 25 & - & & \\
\hline \multirow{2}{*}{ Alta } & $45 \mathrm{~A}$ & 20 & - & \multirow{2}{*}{45} & \multirow{2}{*}{65} \\
\hline & 45 & - & 30 & & \\
\hline \multirow{2}{*}{ Media } & $35 \mathrm{~A}$ & 13,5 & - & \multirow{2}{*}{35} & \multirow{2}{*}{55} \\
\hline & 35 & - & 20 & & \\
\hline Baja & 25 & - & 15 & 25 & - \\
\hline
\end{tabular}

TABLE 2

Strength Categories and Classes of Cements I-IV

\begin{tabular}{|c|c|c|c|c|c|}
\hline \multirow{2}{*}{$\begin{array}{l}\text { Strength } \\
\text { Categories }\end{array}$} & \multirow{2}{*}{ Classes } & \multicolumn{4}{|c|}{ Compression Strength $\left(\mathrm{N} / \mathrm{mm}^{2}\right)$} \\
\hline & & $\begin{array}{l}\text { Minimum at } \\
2 \text { days }\end{array}$ & $\begin{array}{l}\text { Minimum at } \\
7 \text { days }\end{array}$ & $\begin{array}{l}\text { Minimum at } \\
28 \text { days }\end{array}$ & $\begin{array}{l}\text { Maximum at } \\
28 \text { days }\end{array}$ \\
\hline \multirow{2}{*}{ Very high } & $55 \mathrm{~A}$ & 30 & - & \multirow{2}{*}{55} & \multirow{2}{*}{ - } \\
\hline & 55 & 25 & - & & \\
\hline \multirow{2}{*}{ High } & $45 \mathrm{~A}$ & 20 & - & \multirow{2}{*}{45} & \multirow{2}{*}{65} \\
\hline & 45 & - & 30 & & \\
\hline \multirow{2}{*}{ Medium } & $35 \mathrm{~A}$ & 13,5 & - & \multirow{2}{*}{35} & \multirow{2}{*}{55} \\
\hline & 35 & - & 20 & & \\
\hline Low & 25 & - & 15 & 25 & - \\
\hline
\end{tabular}


TABLA 3

Categorías resistentes y clases de cementos mixtos $V$

\begin{tabular}{|c|c|c|}
\hline \multirow{2}{*}{$\begin{array}{c}\text { Categorías } \\
\text { Resistentes }\end{array}$} & Clases & Resistencias a compresión $\left(\mathbf{N} / \mathbf{m m}^{2}\right)$ \\
\cline { 3 - 3 } & & Mínimas a 90 días \\
\hline Baja & 25 & 25 \\
\hline Media & 35 & 35 \\
\hline
\end{tabular}

TABLE 3

Strength categories and classes of cement blends $V$

\begin{tabular}{|c|c|c|}
\hline \multirow{2}{*}{$\begin{array}{c}\text { Strength } \\
\text { Categories }\end{array}$} & Classes & Compression Strength $\left(\mathbf{N} / \mathbf{m m}^{2}\right)$ \\
\cline { 2 - 3 } & & Minimun at 90 days \\
\hline Low & 25 & 25 \\
\hline Medium & 35 & 35 \\
\hline
\end{tabular}

TABLA 4

Categoría resistente y clase de los cementos aluminosos VI

\begin{tabular}{|c|c|c|c|}
\hline \multirow{2}{*}{$\begin{array}{c}\text { Categoría } \\
\text { Resistente }\end{array}$} & Clase & \multicolumn{2}{|c|}{ Resistencias a compresión (N/mm²) } \\
\cline { 3 - 4 } & & Mínima a 2 días & Mínima a 28 días \\
\hline Muy alta & 55 & 45 & 55 \\
\hline
\end{tabular}

TABLE 4

Strength categories and classes of aluminous cements VI

\begin{tabular}{|c|c|c|c|}
\hline \multirow{2}{*}{$\begin{array}{c}\text { Strength } \\
\text { categories }\end{array}$} & \multirow{2}{*}{ Classes } & \multicolumn{2}{|c|}{ Compression Strength (N/mm $\left.{ }^{2}\right)$} \\
\cline { 3 - 4 } & & Minimum at 2 days & Minimum at 28 days \\
\hline Very high & 55 & 45 & 55 \\
\hline
\end{tabular}


TABLA 5

Especificaciones físicas para todos los tipos de cementos

\begin{tabular}{|c|c|c|c|}
\hline \multirow{2}{*}{$\begin{array}{c}\text { Categorías } \\
\begin{array}{c}\text { Resistentes } \\
\text { (1) }\end{array}\end{array}$} & $\begin{array}{c}\text { Principio } \\
\text { Minutos }\end{array}$ & $\begin{array}{c}\text { Final } \\
\text { Horas }\end{array}$ & $\begin{array}{c}\text { Expansión Chatelier } \\
\text { máx. mm }\end{array}$ \\
\cline { 2 - 4 } & $>45$ & $<12$ & 10 \\
\hline Muy alta & $>60$ & $<12$ & 10 \\
\hline Alta, media, baja & &
\end{tabular}

(1) Véase categorías resistentes en las tablas 2, 3 y 4.

TABLA 6

Prescripciones relativas a las características químicas

\begin{tabular}{|c|c|c|c|c|c|c|c|c|c|c|c|c|}
\hline \multirow{3}{*}{$\begin{array}{l}\text { Caracteristicas } \\
\text { químicas }\end{array}$} & \multicolumn{12}{|c|}{ Tipos de cemento } \\
\hline & \multirow{2}{*}{$\begin{array}{l}\text { 1.0 } \\
\text { Port- } \\
\text { land }\end{array}$} & \multirow{2}{*}{$\begin{array}{l}1 \\
\text { Pori- } \\
\text { land }\end{array}$} & \multicolumn{5}{|c|}{ II Portland con } & \multirow{2}{*}{$\begin{array}{l}\text { lll-1 } \\
\text { Horno } \\
\text { alto }\end{array}$} & \multirow{2}{*}{$\begin{array}{l}\text { Ill-2 } \\
\text { Horno } \\
\text { alto }\end{array}$} & \multirow{2}{*}{$\begin{array}{c}\text { IV } \\
\text { Puzo- } \\
\text { lánico }\end{array}$} & \multirow{2}{*}{$\begin{array}{c}\text { y } \\
\text { Mixto }\end{array}$} & \multirow{2}{*}{$\begin{array}{c}\text { VI } \\
\text { Alu- } \\
\text { minoso }\end{array}$} \\
\hline & & & $\begin{array}{l}\text { Comr } \\
\text { puesto }\end{array}$ & $\begin{array}{c}\text { Escoria } \\
\mathrm{S}\end{array}$ & $\begin{array}{l}\text { Puzo- } \\
\text { lana } \\
\mathbf{Z}\end{array}$ & $\begin{array}{l}\text { Ceniza } \\
\text { volante } \\
\text { C }\end{array}$ & $\begin{array}{l}\text { Filler } \\
\text { calizo } \\
\text { F }\end{array}$ & & & & & \\
\hline $\begin{array}{l}\text { Pérdida al fuego } \\
\text { PF }\end{array}$ & 3,5 & 5 & 7 & 5 & 7 & 7 & 7 & 5 & 5 & 8 & 12 & - \\
\hline $\begin{array}{l}\text { Residuo insoluble } \\
\text { RI Max \% }\end{array}$ & 2,5 & 5 & - & 5 & - & - & 5 & 5 & 5 & - & - & - \\
\hline $\begin{array}{l}\text { Trióxido de azufre } \\
\mathrm{SO}_{3} \\
\qquad \mathrm{Max} \%\end{array}$ & $\begin{array}{c}4\left(^{+}\right) \\
0 \\
4,5\end{array}$ & $\begin{array}{c}4(*) \\
0 \\
4,5\end{array}$ & 4,5 & 4,5 & 4 & 4 & 4 & 4,5 & 4,5 & 4 & 4,5 & - \\
\hline $\begin{array}{l}\text { Cloruros } \\
\mathrm{Cl}^{-}\end{array}$ & 0,1 & 0,1 & 0,1 & 0,1 & 0,1 & 0,1 & 0,1 & 0,1 & 0,1 & 0,1 & 0,1 & 0,1 \\
\hline $\begin{array}{l}\text { Sulfuros } \\
\text { S= }\end{array}$ & - & - & - & - & - & - & - & - & - & - & - & 0,1 \\
\hline $\begin{array}{l}\text { Óxido de aluminio } \\
\mathrm{Al}_{2} \mathrm{O}_{3} \quad \mathrm{Min} \%\end{array}$ & - & - & - & - & - & - & - & - & - & - & - & 36 \\
\hline $\begin{array}{l}\text { Puzolanicidad } \\
8 \text { ó } 15 \text { días }\end{array}$ & - & 一 & - & - & - & - & - & - & - & $\begin{array}{l}\text { Cumplirá } \\
\text { el ensayo } \\
\text { de puzo- } \\
\text { lanicidad }\end{array}$ & - & - \\
\hline
\end{tabular}

(*) 4 para la clase 35 y 4,5 para las clases 45 y 55 .

\section{CONCLUSIONES}

Como conclusión, a lo largo de la historia los cementos han evolucionado en distintos aspectos.

En primer lugar, el número de tipos ha crecido gradualmente al incorporar adiciones de distinta clase y proporción y surgir otros con propiedades o características adicionales.

Asimismo, las mejoras en el proceso tecnológico de fabricación (molienda más profunda y

\section{CONCLUSION}

Throughout their history, cements are shown to have undergone a considerable development in different aspects.

In the first place, the number of types has gradually increased, due to the incorporation of different additives at different ratios and the development of cements with additional and enhanced propertie and features.

By the same token, technological improvements in the manusfacturing process (more thorough and 
TABLE 5

Physical specifications for all cement types

\begin{tabular}{|c|c|c|c|}
\hline \multirow{2}{*}{$\begin{array}{c}\text { Strength } \\
\text { category } \\
(1)\end{array}$} & $\begin{array}{c}\text { Initial } \\
\text { minutes }\end{array}$ & $\begin{array}{c}\text { Fetting } \\
\text { hours }\end{array}$ & $\begin{array}{c}\text { Le Chatelier } \\
\text { máx. mm }\end{array}$ \\
\cline { 2 - 4 } & $>45$ & $<12$ & 10 \\
\hline Very high & $>60$ & $<12$ & 10 \\
\hline High, medium, low & & & \\
\hline
\end{tabular}

(1) Cf. Strength categories in Tables 2, 3 and 4.

TABLE 6

Requirements regarding chemical characteristics

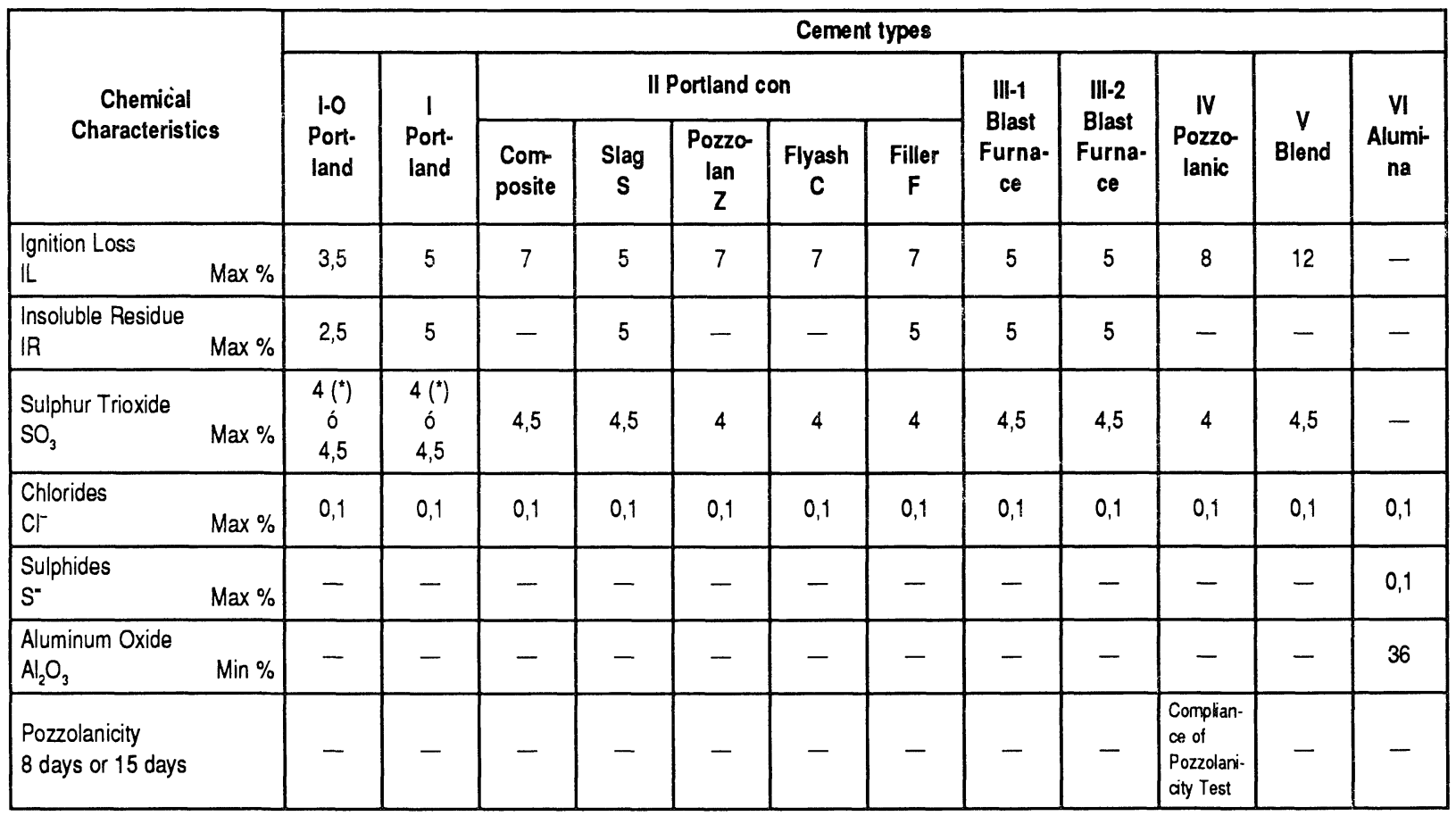

(') 4 for class 35 and 4.5 for classes 45 and 55 .

controlada y mayores temperaturas en los hornos) han permitido elevar gradualmente la categoría resistente para todos los cementos.

En cuanto a especificaciones químicas éstas han tendido a reducirse y significarse. De la inclusión de módulos (más adecuados para controlar el proceso de fabricación), pasando por limitaciones ambiguas on algunos óxidos $\left(\mathrm{MgO}+\mathrm{SO}_{3}\right.$; cal liberada en cementos puzolánicos, etc.), y elevando gradualmente otros que hoy permanecen (RI, $\mathrm{PF}, \mathrm{SO}_{3}$ ), se empieza a hablar de composición potencial a partir de 1961, estableciendo limitaciones, principalmente, en lo que se refiere al contenido de $\mathrm{C}_{3} \mathrm{~A}$. controlled grinding and higher furnace temperatures) have permitted to gradually raise the strength category for all cements.

Regarding the chemical specifications, they have been reduced and become more relevant. From the incorporation of moduli (better suited for process control), over a period of ambiguous limits for some oxide $\left(\mathrm{MgO}+\mathrm{SO}_{3}\right.$, lime release in pozzolanic cements, etc.), and raising gradually others still valid today (RI, PF, $\left.\mathrm{SO}_{3}\right)$ as of 1961 the term potential composition finds its way into the specifications, establish ing limits principally for $C_{3} A$ content. 
Las especificaciones físicas han quedado limitadas, en el tiempo, al fraguado y a la estabilidad de volumen medido con las agujas de Le Chatelier. Han desaparecido las limitaciones en peso específico, finura (tanto residuo en tamiz como superficie específica) y estabilidad de volumen por el ensayo de autoclave.

Desde el punto de vista mecánico se han aumentado gradualmente los niveles de las categorías resistentes, quedando establecido hoy día un rango que oscila de 25 a $55 \mathrm{~N} / \mathrm{mm}^{2}$ en 4 categorías (muy alta, alta, media y baja). En cementos de alta resistencia inicial se fija un mínimo resistente a 2 días y, en todos los casos, un mínimo y un máximo a la edad de especificación (28 días).
The physical specifications have been reduced, in the course of time, to setting values and volume stability as measured with Le Chatelier needles. Specific weight, fineness (sieve residue as well as specific surface) and autoclave assay volume stability have disappeared.

From the mechanics point of view the levels of high strength categorie have been increasing, at present in the range of $25-55 \mathrm{~N} / \mathrm{mm}^{2}$ in 4 categories (especially high, high, medium, low). For high early strength cements minimum strength at 2 days ageing is established, and for all categories maximum and minimum values at the specification age (28 days).

\section{monografía del ICCET/CSIC (n. $\left.{ }^{\circ} 402\right)$}

Madrid, septiembre 1990

El vidrio se puede obtener a partir de múltiples composiciones, lo que da lugar a propiedades diversas y aplicaciones muy diferentes.

La Monografía consta de cuatro partes. La primera está dedicada a hacer una exposición, no demasiado minuciosa, sobre el vidrio en general.

En la segunda se describe la acción que la radiación luminosa (solar) ejerce sobre diferentes tipos de vidrios. Se hace un estudio de los tres fenómenos principales producidos en el vidrio por efecto de dicha radiación:

- La fluorescencia.

- La solarización.

- El fotocromismo.

La tercera parte hace referencia al aprovechamiento de la radiación solar y el papel que el vidrio tiene en esta captación.

En la cuarta se incluye una recopilación de trabajos de investigación, realizados por la autora, en los que se han preparado diferentes vidrios aplicables como captadores de la Energía Solar. 